\section{Genotypic Variation in Flower Induction and Development in Hydrangea macrophylla}

\author{
Warner Orozco-Obando, Gwen N. Hirsch, and Hazel Y. Wetzstein ${ }^{1}$ \\ Department of Horticulture, University of Georgia, 1111 Miller Plant Sciences \\ Building, Athens GA 30602
}

Additional index words. flower induction, flower development, flower initiation, bigleaf hydrangea, Hortensia, cultivars

\begin{abstract}
The general doctrine of flowering in Hydrangea macrophylla (Thunb.) Ser. is that floral induction occurs during the fall months with the flower appearing the following spring or summer. However, hydrangea cultivars differ widely in their relative abundance and duration of flower production. The objective of this study was to determine how developmental flowering patterns compared among different hydrangea genotypes. Flowering was characterized in $\mathbf{1 8}$ cultivars by assessing flower initiation in dormant buds of 1-year-old stems that received natural outdoor inductive conditions. Terminal and lateral buds were dissected and floral developmental stage categorized microscopically. In terminal buds, flower development was very consistent and occurred in $100 \%$ of buds for all cultivars except 'Ayesha' $(33 \%)$. In contrast, lateral buds showed a wide variation in flower induction among genotypes. 'Ayesha', 'Blushing Pink', 'Freudenstein', and 'Nigra' had $10 \%$ or fewer lateral buds with floral initials. 'All Summer Beauty', 'David Ramsey', 'Masja', 'Nightingale', and 'Penny Mac' showed high levels of floral induction ( $>92 \%)$. Within a cultivar, flower development was more advanced in terminal than lateral buds. In several cultivars, a significant correlation between bud size (length) and floral stage was found. However, low r-square values indicated that flower stage was explained largely due to factors other than bud length. This study shows that floral induction patterns vary markedly among hydrangea cultivars and provides insight into why cultivars differ in the extent and reliability of seasonal blooming. Genotypes that possess floral primordia in lateral buds would be amenable to cultural practices that enhance lateral budbreak and recurrent blooming.
\end{abstract}

Hydrangea macrophylla is by far the most well-known species in the genus, and from it, hundreds of named cultivars have been selected or developed over the years throughout the world (van Gelderen and van Gelderen, 2004). The popularity of hydrangea is due in part to its versatility as both a florist and landscape plant. In the garden, the plant forms a rounded or mounded shrub composed of erect, usually unbranched stems that can reach $2 \mathrm{~m}$. Hydrangea macrophylla is a desirable ornamental plant because it has immense variation in flower size, shape and color. In addition, it performs well with relatively little maintenance because it has characteristics such as ease of cultivation, few pests and diseases, shade tolerance and adaptability to alkaline and acid soils.

The general doctrine of flowering in $H$. macrophylla is that floral induction occurs during the previous season, with the flower appearing the following year (Zhou and Hara, 1988). Plants in their native habitat initiate inflorescences under the cool, short-day conditions of fall, then bloom in spring with the resumption of growth, making its flowering pattern similar to that of azaleas (Bailey and Weiler, 1984). However, hydrangea cultivars exhibit great variability in the abundance and

Received for publication 16 June 2005. Accepted for publication 26 June 2005.

${ }^{1}$ To whom reprint requests should be addressed; e-mail hywetz@uga.edu. duration offlower production. Recentreports of throughout the growing season (Adkins and Dirr, 2003; Dirr, 2004; Haworth-Booth, 1984; the attention of the industry, breeders, researchrow hydrangea enthusiasts. In hydrangea, temperatures cause flower bud differentiation days promote vegetative growth while short above the optimum, no effect within the optimum range of inducti temperatures (Wallerstein and Runger, 1985).

Detailed developmental studies evaluating flowering patterns in H. macrophylla are lack- ing, as are evaluations of how flower induction and development compare in different cultivars. The objective of this study was to determine how developmental flowering patterns compare among $18 \mathrm{H}$. macrophylla genotypes after exposure to natural inductive conditions. The intent of the study was to determine the location and frequency of floral development, i.e., the extent of flower bud induction in terminal and lateral buds, and the degree of variability in different genotypes. Such fundamental information about flower induction patterns can be used to develop cultural practices to promote enhanced flower production.

\section{Materials and Methods}

Plant materials. Flowering was characterized in 18 cultivars of $H$. macrophylla including 'All Summer Beauty', 'Ayesha', 'Blushing Pink', 'Charm Red', 'Compacta', 'David Ramsey', 'Dooley', 'Freudenstein', 'General Vicomtesse de Vibraye', 'Kardinal', 'Lady Fugino', 'Lilacina', 'Masja', 'Nightingale', 'Nigra', 'Nikko Blue', 'Penny Mac', and 'Veitchii'. Stems were harvested from plants growing in the hydrangea collection at the University of Georgia (UGA) Shade Garden on the UGA campus, Athens, or at the Center for Applied Nursery Research in Dearing, $\mathrm{Ga}$. The plants from which the shoots were harvested had been exposed to natural outdoor floral inductive conditions (short days and low temperatures during fall and winter). For each cultivar, four to ten 1-year-old dormant shoots with terminal buds were collected during the second week of February 2003. Shoots were brought back to the lab to microscopically assess the extent of flower initiation and development within the terminal and lateral buds.

Stem, bud and reproductive characterization. The location (terminal vs. lateral) and length of all buds were recorded. All buds longer than $2 \mathrm{~mm}$ were dissected to expose the shoot apex. Bud scales and leaf primordia were excised with a scalpel and the exposed apices were then examined under a stereomicroscope to determine if they were vegetative or reproductive. Apices were classified according to their stage of development (Table 1) ranging from those having a vegetative apex (Stage 1) to those with differentiated florets with expanded sepals enclosing the floral apex (Stage 5) (Fig. 1 ). Any bud identified at stage 2 or greater was classified as induced.

Scanning electron microscopy. Representative apices were fixed and prepared for scanning electron microscopy to document the standards of developmental characteristics for our floral stage rankings. Tissues were fixed in $2 \%$ glutaraldehyde in $0.1 \mathrm{M}$ cacodylate buffer, $\mathrm{pH}$ 7.2, dehydrated through an ethanol series,

\begin{tabular}{ll} 
Table 1. Stages of Hydrangea & macrophylla inflorescence development. \\
\hline Stage & Characteristic \\
\hline 1 & Vegetative apex. Meristem is covered by the upper pair of leaf primordia. \\
2 & $\begin{array}{c}\text { Transition to a floral apex. Apex is broadened, swollen, dome-shaped and } \\
\text { the upper pair of leaf primordia are separated }\end{array}$ \\
3 & Individual floral primordia are defined within the inflorescence. \\
4 & Sepal primordia are initiated on flowers. \\
5 & Florets are well-defined; sepal primordia enclose the floral apex.
\end{tabular}

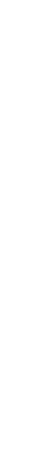

.

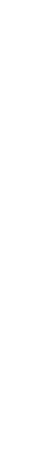

. 
and critical point dried through $\mathrm{CO}_{2}$ using a Samdri-780 critical point drying apparatus (Tousimis Research Corporation, Rockville, Md.). Samples were mounted on aluminum stubs, further dissected if necessary, sputtercoated with gold, and observed with a scanning electron microscope (JSM-5800, JEOL, Tokyo, Japan). Some critical point dried tissues were observed and photographed under a dissecting microscope.

Quantitative and statistical analyses. Morphological and developmental data were compared using mean separation by StudentNewman-Keuls $(P \leq 0.05$ or 0.10$)$ with the PROC GLM function of SAS (SAS Institute Inc., Cary, N.C.). Bud length and floral stage development were analyzed using Pearson correlation coefficients. Descriptive statistics of the data were generated with Excel Graph Wizard (Microsoft, Redmond, Wash.) and Sigma Plot 8.0 (SPSS Inc. Chicago, Ill).

\section{Results}

Terminal bud development. Terminal buds exhibited consistently high levels of flower induction with all cultivars achieving 100\% induction with the exception of 'Ayesha' which had only $33 \%$ induction (Table 2). Mean floral bud developmental stages ranged from 2.8 to 5.0. With the exception of 'Nigra' and 'Ayesha', there were few significant differences in floral stage among cultivars. 'Nigra' (with a mean stage of 2.8) had significantly less advanced floral development than all cultivars except for 'Ayesha' and 'Compacta'.
Lateral bud induction and development. Cultivars exhibited a wide range in the percentage of lateral buds that were reproductive (Table 2). 'David Ramsey', 'Nightingale', 'All Summer Beauty', 'Masja', and 'Penny Mac' had over $90 \%$ of their lateral buds with floral primordia. In contrast, 'Ayesha', 'Blushing Pink', 'Freudenstein', and 'Nigra' exhibited $10 \%$ or fewer lateral buds with floral initials. Other cultivars were intermediate in the percentage of induction (ranging from 59 to $88 \%$ induction). In general, the stage of floral development in induced buds was not significantly different among cultivars, and ranged from a mean of 2.1 (apical meristem has an open, dome-shaped form) to 3.5 (inflorescence is well-formed and expanding).

Bud size and flower development. Correla-
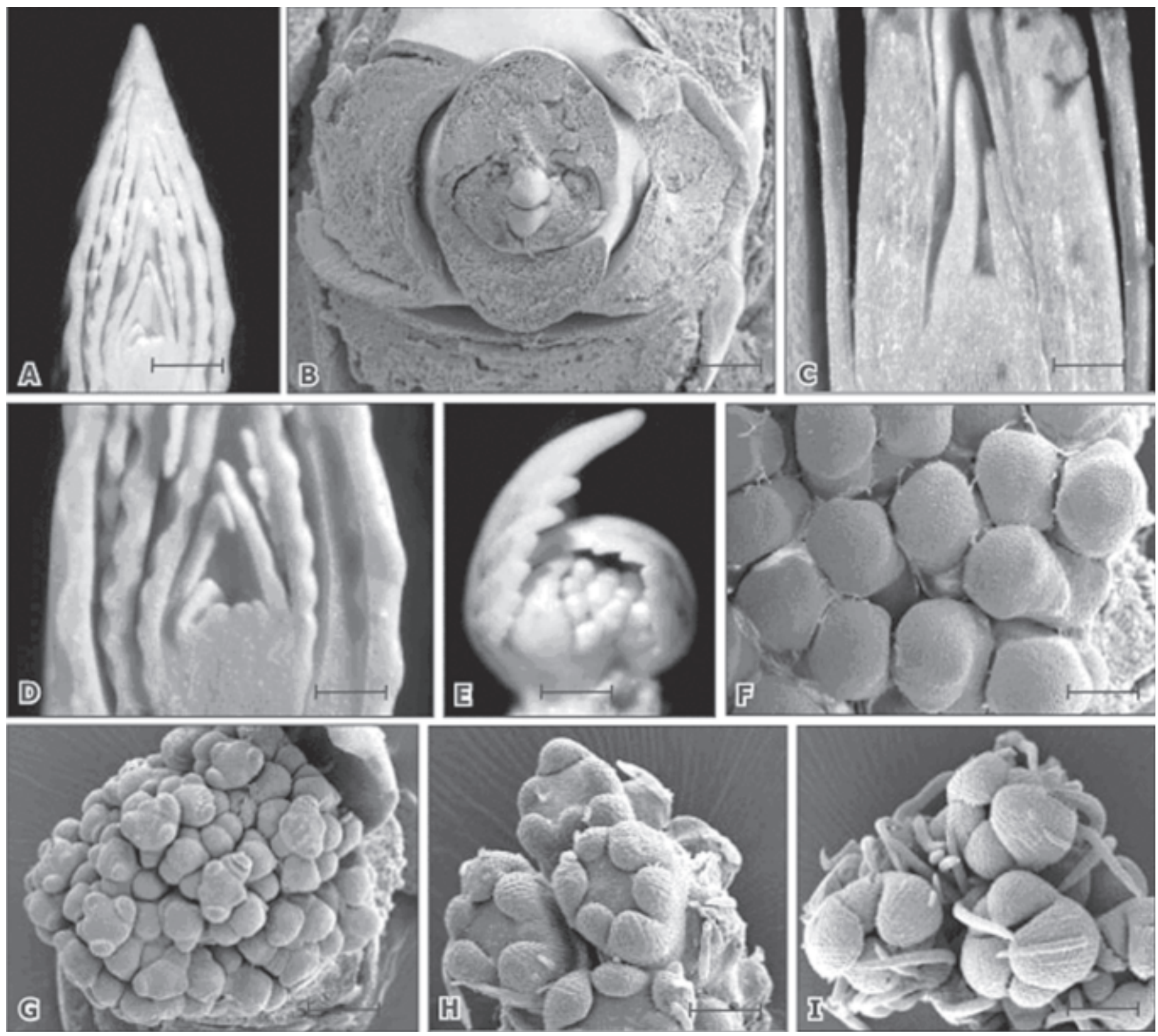

G

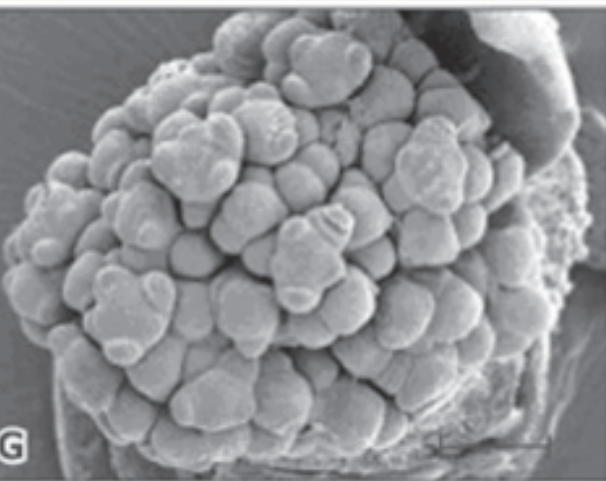

Fig. 1. Light micrographs (LMs) and scanning electron micrographs (SEMs) of Hydrangea macrophylla meristems dissected from dormant buds. (A) (LM) A longitudinal section of a bud showing numerous leaf primordia surrounding the shoot meristem. Bar $=1000 \mu \mathrm{m}$. (B) (SEM) Apical view of a vegetative meristem. Leaf scars of detached leaf primordia surround the apical meristem. Bar $=200 \mu \mathrm{m}$. (C) $(\mathrm{LM})$ Vegetative meristem at stage 1. Bar $=200 \mu \mathrm{m}$. (D) (LM) Stage 2 meristem with broadened apex. Bar $=260 \mu \mathrm{m}$. (E) (LM) Floral primordia are defined, stage 3. Bar $=750 \mu \mathrm{m}$. (F) (SEM) Closer view of stage 3 meristem showing rounded floral apices. Bar $=150 \mu \mathrm{m}$. (G) $(\mathrm{SEM})$ Flower primordia have initiated sepal primordia, stage 4. Bar $=175 \mu \mathrm{m}$. $(\mathbf{H})(\mathrm{SEM})$ Closer view of flowers with sepals, stage 4 . Bar $=100 \mu \mathrm{m}$. (I) (SEM) Flowers with sepals enclosing the floral apex, stage 5 . Bar $=200 \mu \mathrm{m}$. 
tion analysis was conducted to determine if there was a relationship between bud length and floral development stage. In several cultivars, bud length and floral stage were positively correlated with longer buds exhibiting more advanced floral development (Table 3). Our data show that cultivars varied in mean bud length (Table 3), but this was not necessarily associated with percent floral induction or floral developmental stage (Table 2). For example, 'Blushing Pink' had the largest lateral buds with a mean length of $18.9 \mathrm{~mm}$, but meristems were not florally induced. In the case of 'Ayesha', mean bud length was fairly large at $11.3 \mathrm{~mm}$ long, but floral stage was 1.2 and only $10 \%$ of the buds were induced. 'David Ramsey' on the other hand, had a high degree of floral development (3.1) and showed 95\% flower induction, yet buds were small (mean length was $6.5 \mathrm{~mm}$ ).

\section{Discussion}

We documented that flower induction in H. macrophylla occurs in both terminal and lateral buds. With the exception of one cultivar, flower-bud induction was observed in $100 \%$ of the terminal buds. The breaking of terminal buds when shoot growth resumes in the spring would correspond to the production of high flower numbers. Flower-bud induction among the 18 cultivars proceeded similarly to the descriptions provided by several authors, i.e., under inductive conditions, H. macrophylla initiated flower-bud differentiation in apical buds (Shanks et al., 1986; Wallerstein and Rünger, 1985; Yeh and Chiang, 2001). Zhou and Hara (1988) found that the leaves and inflorescences of flower-bearing hydrangea shoots were normally preformed in the terminal bud during the previous year. In contrast to our current study, their evaluations of the structure of winter buds indicated a lack of flower initiation in lateral buds. They found that although the shoot apex of terminal buds was reproductive, those of axillary buds showed a concave form lacking inflorescence primordia. Zhou and Hara did not specify specific cultivars used in their evaluation. The occurrence of floral primordia in lateral buds has previously been postulated (Adkins, 2001; Armitage and Laushman, 2003; Dirr, 2004), but not verified.

Our observations were that flower induction in lateral buds varied markedly according to genotype, from those exhibiting $>90 \%$ induced buds to those with $<10 \%$ induction. The variability of floral induction in lateral buds among genotypes may help to explain why some cultivars differ in their blooming seasons and why some cultivars are more reliable bloomers than others. Cultivars with flower buds confined primarily to terminal buds may be restricted in their blooming to the period of early season shoot expansion. Furthermore, if terminal flower buds are lost due to mechanical damage, cold-injury or careless pruning, little or no bloom would occur that season. In our study, we would predict 'Ayesha' would have limited bloom, as only $33 \%$ of terminal buds had developed inflorescences, and only 10\% of lateral buds were reproductive. Similarly, it could be projected that 'Freudenstein', 'Blushing Pink', and 'Nigra' would exhibit unreliable blooming if the terminal buds were lost because the percentage of floral induction in lateral buds was low. In contrast, cultivars like 'David Ramsey', 'All Summer Beauty', 'Masja', 'Nightingale', and 'Penny Mac' exhibited greater percentages of floral induction in lateral buds and would have the capacity to flower even if terminal buds were lost from cold or injury.

We did not find a consistent pattern of correlation between bud length and floral development stage. Although correlation coefficients were highly significant in some cases, $r^{2}$ values were characteristically low ( 0.04 to $0.46)$. Low $r^{2}$ values in the correlations between bud length and floral development indicated that within a cultivar, flower development is explained largely due to factors other than bud size. Other factors such as bud position, stem type, cultivar sensitivity and environment can influence bud size.

The identification of reblooming culti-

Table 2. Percentage of floral induction and mean floral development stage in terminal and lateral buds

\begin{tabular}{|c|c|c|c|c|}
\hline \multirow[b]{2}{*}{ Cultivar } & \multicolumn{2}{|c|}{ Terminal buds } & \multicolumn{2}{|c|}{ Lateral buds } \\
\hline & $\%$ & $\begin{array}{c}\text { Mean floral stage } \\
\text { of induced buds }\end{array}$ & $\%$ & $\begin{array}{c}\text { Mean floral stage } \\
\text { of induced buds }\end{array}$ \\
\hline All Summer Beauty & $100(7)^{z}$ & $4.3 \mathrm{ab}^{\mathrm{y}}$ & $92(36)^{z}$ & $3.4 \mathrm{a}^{\mathrm{y}}$ \\
\hline Ayesha & $33(9)$ & $3.0 \mathrm{~cd}$ & $10(38)$ & $2.1 \mathrm{~b}$ \\
\hline Blushing Pink & $100(4)$ & $4.0 \mathrm{abc}$ & $0(13)$ & --- \\
\hline Charm Red & $100(10)$ & $4.3 \mathrm{ab}$ & $83(102)$ & $2.8 \mathrm{ab}$ \\
\hline Compacta & $100(9)$ & $3.4 \mathrm{bcd}$ & $86(6)$ & $2.6 \mathrm{ab}$ \\
\hline David Ramsey & $100(7)$ & $4.4 \mathrm{ab}$ & $95(21)$ & $3.4 \mathrm{a}$ \\
\hline Dooley & $100(5)$ & $4.0 \mathrm{abc}$ & $82(31)$ & $2.5 \mathrm{ab}$ \\
\hline Freudenstein & $100(5)$ & $3.9 \mathrm{abc}$ & $10(20)$ & $3.0 \mathrm{ab}$ \\
\hline General Vic. De Vibraye & $100(5)$ & $4.8 \mathrm{a}$ & $88(31)$ & $3.2 \mathrm{a}$ \\
\hline Kardinal & $100(9)$ & $3.9 \mathrm{abc}$ & $88(29)$ & $3.5 \mathrm{a}$ \\
\hline Lady Fugino & $100(4)$ & $4.3 \mathrm{ab}$ & $71(49)$ & $2.4 \mathrm{ab}$ \\
\hline Lilacina & $100(4)$ & $4.0 \mathrm{abc}$ & $73(25)$ & $2.8 \mathrm{ab}$ \\
\hline Masja & $100(6)$ & $4.5 \mathrm{ab}$ & $100(66)$ & $2.9 \mathrm{ab}$ \\
\hline Nightingale & $100(6)$ & $4.2 \mathrm{ab}$ & $100(52)$ & $3.2 \mathrm{a}$ \\
\hline Nigra & $100(5)$ & $2.8 \mathrm{~d}$ & 0 (19) & --- \\
\hline Nikko Blue & $100(4)$ & $5.0 \mathrm{a}$ & $81(16)$ & $3.1 \mathrm{ab}$ \\
\hline Penny Mac & $100(6)$ & $4.3 \mathrm{ab}$ & $93(42)$ & $2.9 \mathrm{ab}$ \\
\hline Veitchii & $100(6)$ & $4.5 \mathrm{ab}$ & $59(28)$ & $2.4 \mathrm{ab}$ \\
\hline
\end{tabular}

zThe numbers in parenthesis indicate the number of buds evaluated.

${ }^{y}$ Means with the same letter are not significantly different (Student Newman-Keuls test) at $P \leq 0.05$.

Table 3. The relationship between bud length and floral stage for different Hydrangea cultivars.

\begin{tabular}{|c|c|c|c|c|c|}
\hline Cultivar & $\begin{array}{l}\text { Bud } \\
\text { length } \\
(\mathrm{mm})\end{array}$ & $\begin{array}{l}\text { Mean } \\
\text { floral } \\
\text { stage }\end{array}$ & $\begin{array}{l}\text { Buds } \\
\text { (no.) }\end{array}$ & Significance & $r^{2}$ \\
\hline All Summer Beauty & $9.2+3.7$ & $3.0+1.2$ & 36 & $* *$ & 0.46 \\
\hline Ayesha & $11.3+4.8$ & $1.2+0.5$ & 38 & NS & 0.04 \\
\hline Blushing Pink & $18.9+5.2$ & $1.0+0.0$ & 13 & --- & --- \\
\hline Charm Red & $9.6+4.4$ & $2.5+0.8$ & 102 & * & 0.04 \\
\hline Compacta & $3.6+2.4$ & $2.3+0.8$ & 6 & NS & 0.37 \\
\hline David Ramsey & $6.5+3.7$ & $3.1+1.1$ & 21 & * & 0.23 \\
\hline Dooley & $5.7+3.0$ & $2.1+0.8$ & 31 & ** & 0.31 \\
\hline Freudenstein & $8.9+4.2$ & $1.2+0.6$ & 20 & NS & 0.07 \\
\hline Gen.Vic. de Vibraye & $11.3+3.4$ & $2.9+0.8$ & 31 & $*$ & 0.15 \\
\hline Kardinal & $10.2+5.7$ & $3.4+0.6$ & 29 & ** & 0.37 \\
\hline Lady Fugino & $5.2+3.0$ & $2.0+0.8$ & 49 & NS & 0.04 \\
\hline Lilacina & $8.5+4.3$ & $3.2+1.3$ & 25 & $* *$ & 0.31 \\
\hline Masja & $9.0+3.5$ & $2.9+0.2$ & 66 & * & 0.06 \\
\hline Nightingale & $8.5+4.5$ & $3.1+0.6$ & 52 & $* *$ & 0.16 \\
\hline Nigra & $8.2+2.5$ & $1.0+0.0$ & 19 & --- & --- \\
\hline Nikko Blue & $10.7+5.9$ & $2.7+1.0$ & 16 & $* *$ & 0.42 \\
\hline Penny Mac & $10.3+4.2$ & $2.6+0.7$ & 42 & $* *$ & 0.38 \\
\hline Veitchii & $10.0+4.3$ & $1.9+0.9$ & 28 & NS & 0.07 \\
\hline
\end{tabular}

${ }^{\mathrm{z}}$ Coefficient is based on Pearson correlation coefficients analysis.

NS, ${ }^{* * *}$ Nonsignificant or significant at $P \leq 0.05$ or 0.10 , respectively. 
Wetzstein, unpublished observations).

Although claims of reflowering ability have been made for some $H$. macrophylla cultivars in nursery and trade publications, support by experimental investigations is generally lacking (Reed, 2002). Evaluations of reblooming behavior often have as much discrepancy as agreement. Nonetheless, we found that some cultivars noted to be reblooming exhibited considerable levels of floral initiation in lateral buds, namely 'All Summer Beauty', 'Dooley', and 'Penny Mac' (Atkins and Dirr, 2003; Bir and Conner, 2002). 'Ayesha' noted as not being a reblooming cultivar (Bir and Conner, 2002; Haworth-Booth, 1984) had low levels of lateral bud induction. 'General Vicomtesse de Vibraye', rated as both nonreflowering and reflowering, had relatively high levels of floral induction. Inconsistencies include 'Masja', which had $100 \%$ of its lateral buds induced, yet has been cited as a nonreblooming genotype (Birr and Conner, 2002).

The significance of the present work is that it verifies there are genotypic differences in the number and location of flower primordia within dormant buds. This information can provide a developmental basis to explain cultivar differences in seasonal flowering duration in hydrangea, and insight into potential manipulation of shoot growth patterns to promote return bloom. In cultivars having floral induction limited to terminal buds, late-season pruning should be avoided to circumvent removing flower buds. Likewise, freeze injury to terminal buds would be catastrophic to bloom.
Cultivars with floral induction occurring within numerous lateral buds could have very different cultural requirements. For example, late-season pruning to improve plant habit would be acceptable. The uppermost axillary buds of the flower-bearing shoot often begin expanding into new lateral shoots when the flowering phase has ended (Zhou and Hara, 1989). If lateral buds have floral primordia, strategies to enhance lateral budbreak and expansion of late-season shoots could be used to promote recurrent blooming.

\section{Literature Cited}

Adkins, J.A. 2001. Remontant flowering potential of ten Hydrangea macrophylla Taxa. MS thesis. Univ. Ga., Athens.

Adkins, J.A., M.A. Dirr, and O.M. Lindstrom. 2002. Cold-hardiness potential of ten Hydrangea taxa. 2002. J. Environ. Hort. 20:171-174.

Adkins, J.A. and M.A. Dirr. 2003. Remontant flowering potential of ten Hydrangea macrophylla cultivars. HortScience 38:1337-1340.

Armitage, A.M. and J.M. Laushman. 2003. Specialty cut flowers. 2nd ed. Timber Press, Portland, Ore.

Bailey, D.A. 1989. Hydrangea production. Growers Hdbk Ser. vol. 3. Timber Press, Portland, Ore.

Bailey, D.A. and T.C. Weiler. 1984. Control of floral initiation in florists' Hydrangea. J. Amer. Soc. Hort. Sci. 109:785-795.

Bir, R.E. and J.L. Conner. 2002. Reblooming bigleaf hydrangeas. S. Nursery Assn. Res. Conf. 40:125-127

Cody, R. and J. Smith. 1991. Applied statistics and the SAS programming language. 3rd ed. Elsevier Sci. Publ., New York.
Dirr, M.A. 2004. Hydrangeas for the American gardens. Timber Press, Portland, Ore.

Haworth-Booth, M. 1984. The hydrangeas. Constable, London.

Lindstrom, J.T., M.C. Pelto, and M.A. Dirr. 2003. Molecular assessment of remontant (re-blooming) Hydrangea macrophylla cultivars. J. Environ. Hort. 21:57-60.

Reed, S.M. 2001. Verification and establishment of Hydrangea macrophylla 'Kardinal' $\times H$. paniculata 'Brussels Lace' interspecific hybrids. J. Environ. Hort. 19:85-88.

Reed, S.M. 2002. Flowering performance of 21 Hydrangea macrophylla cultivars. J. Environ. Hort. 20:155-160.

Shanks, J.B., H.G. Mityga, and L.W. Douglas. 1986. Photoperiodic responses of Hydrangea. J. Amer. Soc. Hort. Sci. 111:545-548.

van Gelderen, C.J. and D.M. van Gelderen. 2004 Encyclopedia of Hydrangeas. Timber Press, Portland, Ore.

Wallerstein, I. and W. Rünger. 1985. Hydrangea macrophylla, p 173-177. In: A.H. Halevy (ed.). CRC handbook of flowering. vol 3. CRC Press, Boca Raton, Fla.

Wallerstein, I. and W. Runger. 1985. Hydrangea macrophylla, pp. 173-177. In:A.H.Halevy (ed.) CRC handbook of flowering. vol. III. CRC Press, Boca Raton, Fla.

Yeh, D.M. and H.H. Chiang. 2001. Growth and flower initiation in Hydrangea as affected by root restriction and defoliation. Scientia Hort. 91:123-132.

Zhou, T.S. and N. Hara. 1988. Development of shoot in Hydrangea macrophylla. I. Terminal and axillary buds. Bot. Mag. Tokyo 101:281-291.

Zhou, T.S. and N. Hara. 1989. Development of shoot in Hydrangea macrophylla. II. Sequence and timing. Bot. Mag. Tokyo. 102:193-206. 